Cinémas

Revue d'études cinématographiques

Journal of Film Studies

\title{
The Mark of Postmodernism: Reading Roger Rabbit
}

\section{Hugh J. Silverman}

Volume 5, numéro 3, printemps 1995

Cinélekta 1

URI : https://id.erudit.org/iderudit/1001152ar

DOI : https://doi.org/10.7202/1001152ar

Aller au sommaire du numéro

Éditeur(s)

Cinémas

ISSN

1181-6945 (imprimé)

1705-6500 (numérique)

Découvrir la revue

Citer cet article

Silverman, H. J. (1995). The Mark of Postmodernism: Reading Roger Rabbit. Cinémas, 5(3), 151-164. https://doi.org/10.7202/1001152ar

\section{Résumé de l'article}

Who Framed Roger Rabbit? (Zemeckis, 1988) est marqué des traces de la postmodernité. Sous les travestissements d'un simple film d'animation au déploiement technologique spectaculaire, sous le dessin d'un gentil petit lapin alcoolique et inquiet des intentions de sa femme plantureuse se cache " une rupture épistémologique ». L'auteur démontre à quel point le film est emporté dans le jeu effréné de la transgression des frontières, des conventions et des genres, dans les plis multiples des dédoublements des codes, dans la dissémination des citations ironiques. Il montre en quoi Roger Rabbit pourrait être une figure obsolète transformée en héros postmoderne. 


\section{The Mark of Postmodernism : Reading Roger Rabbit}

\section{Hugh J. Silverman}

\section{RÉSUMÉ}

Who Framed Roger Rabbit? (Zemeckis, 1988) est marqué des traces de la postmodernité. Sous les travestissements d'un simple film d'animation au déploiement technologique spectaculaire, sous le dessin d'un gentil petit lapin alcoolique et inquiet des intentions de sa femme plantureuse se cache "une rupture épistémologique ". L'auteur démontre à quel point le film est emporté dans le jeu effréné de la transgression des frontières, des conventions et des genres, dans les plis multiples des dédoublements des codes, dans la dissémination des citations ironiques. Il montre en quoi Roger Rabbit pourrait être une figure obsolète transformée en héros postmoderne.

\section{ABSTRACT}

Who Framed Roger Rabbit? (Zemeckis, 1988) bears the traces of postmodernity. Behind this simple animation film and its spectacular technology, behind these drawings of a cute little alcoholic rabbit anxious about the intentions of his voluptuous wife, lurks an "epistemological rupture." The author demonstrates how the film is caught up in a game of boundaries, conventions and genres transgressed, in multiple folds of codes looping back on themselves, in reiterations of ironic quotes. He shows how Roger Rabbit might be considered an obsolete figure transformed into a postmodern hero.

The scene opens with the woman of the house about to go out. We see only her legs and feet. She will be leaving her 
baby - still crawling and in diapers - with the babysitter. The baby is called Baby Herman. The baby sitter is a rabbit. The rabbit is a rather colorfully clad updated version of Buggs Bunny. His name is Roger. Roger Rabbit has been asked to do a good job this time (or he is threatened with being sent back to the experimental lab). While he is busy trying to remind himself of his child care duties, disaster strikes. Without Roger noticing, the child upon spying a jar of cookies on top of the refrigerator propels himself out of his crib and heads for the object of his desire. The kitchen is turned into a total mess, near mishaps stove turned on, dishwater poured out onto the floor, even the refrigerator itself lands on the babysitter's head as he attemps to restrain his ward from attaining his end. Roger gets rather badly battered by the various kitchen machines which become obstacles in his attempts to perform his babysitting duties.

It look likes the usual slapstick Looney Tunes-type cartoon that many of us grew up on. With the logo for Maroon Cartoons, the film even begins with music that reminds us of those days. We are even unsure as to whether this is not like the "olde" days when the full-length feature at the Movies was almost always preceded by a cartoon. Then we hear the director calling "cut!" "Cut what?" we ask. And before it is clear what is happening, a human comes on followed by the whole camera set. The cartoon characters (Roger Rabbit and Baby Herman) walk off the set and past the camera crew. But something strange has happened. The cartoon characters are still cartoon characters and the humans are still humans. However the human world is already of a by-gone era - around 1947, Hollywood, old-fashioned cars, period clothing. Then we remember that the preview that was shown before the movie began - seemingly outside the frame of the film - was an announcement for the return of Bambi to the "movie theater nearest you" (noting, especially, that Walt Disney's Bambi was copyrighted in 1942). But it is not uncommon for Cinderella (1950), Snow White (1937), 101 Dalmatians (1961), and Pinocchio (1940) revivals, among others, to remind us of our childhood and to help give our children theirs.

But what are we to do - conceptualy - with a film in wich the cartoon characters mingle with the human world and vice 


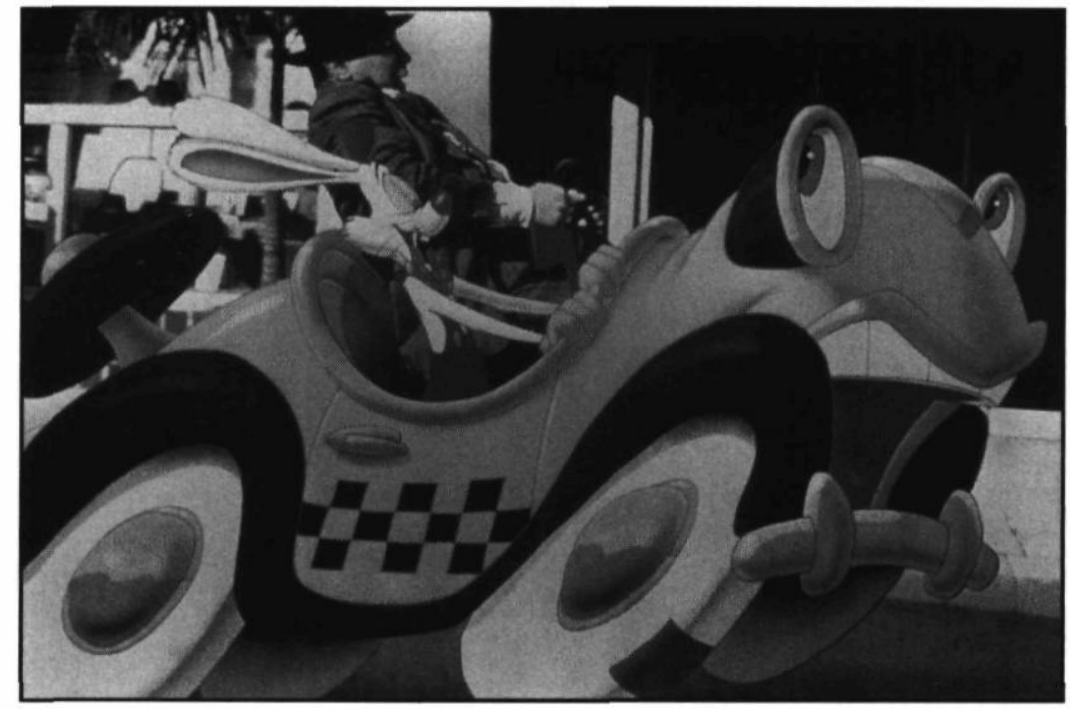

\section{Who Framed Roger Rabbit? by Robert Zemeckis (1988)}

versa. And further how do we sort out the relationship between humans working at a Hollywood studio set in days reminiscent of $\mathrm{Al}$ Capone, Eliot Ness, et al. (even if it is not Chicago although one might sometimes wonder). And then we find Baby Herman is really a grumpy old man - a cartoon actor who has obviously been playing the "baby" role for decades. He knows how it is supposed to go and he is a pro at getting it right. Furthermore he is annoyed at Roger Rabbit because he his not on top of his role - though we might not know it since it looks as though he gets into the usual amount of trouble, has the usual number of dinner pots dropped on the head, the usual getting locked in the stove with the oven accidentally turned on, the typical falling on the floor as the refrigerator drops on his head, and so forth. But we then learn that Roger is not up to form. He is worried about his wife's fidelity. He has been drinking too much. Roger seems to have lost his touch. When the refrigerator hits him on the head birds fly around his head rather than conventional stars. This infuriates the Director.

The scene switches to a rough talking if-he-only-were-Humphrey-Bogart alcoholic detective - Bob Hoskins comes across 
something like Danny DeVito playing Rockford. He his obviously hard up for money - his girlfriend who works in the restaurant is concerned about him, but he owes her money too. Mr. Maroon, the big-time producer, calls him over to his office to conduct an investigation. The detective is given a $50 \$$ advance to take pictures of Roger Rabbit's wife Jessica and to catch her in somne kind of improper behaviour. Hoskins goes to the night club where she works only to learn that she is a beautiful, sensuous, night-club singer. Humans, mostly men, are sitting at their tables waiting for her to come on stage. They are served by penguins - the penguins are of course cartoons. We have become accustomed by this point of dissonance (or catacresis?) produced by a scene peopled by both humans and cartoon figures at the same time. Fortunately the humans are from another era which keeps us from immediate identification and also maintains the juxtaposition. Then Jessica comes on the stage : but she is not an animal cartoon; she is a human cartoon. So Roger Rabbit is married to a human cartoon. We have to keep our categories straight. Sorting them out, we find 1940's humans, cartoon animals who talk, and cartoon humans. They all now occupy the same spaces in Toontown.

The Bob Hoskins detective is effective - though a bit bumbling - at getting pictures of Roger's wife playing "paddy cake" with a dirty-old man Hollywood producer. Roger is floored. He goes out on a binge. And when it is learned that Maroon the Producer, who wanted surrepticious pictures in order to rattle Roger, has been killed, Roger is blamed. But we already know from the title of the film Who Framed Roger Rabbit? that Roger didn't do it. As usual, the question is: who did kill Maroon? The detective is not fond of Toons - he suspects that one of them killed his brother (also a private eye) - but he is not ready to be coopted. The plot thickens as Roger seeks Bob Hoskins' aid. This includes a rather tortuous trip to Toontown - a world filled with all those favorite characters from just about every cartoon genre imaginable from Porky Pig to Dumbo. The sinister figure - seemingly a human by the name of Judge Doom - sends out cartoon weasels after Roger. Judge Doom wants to get rid of all the Toons so that he can sell the 
land to a developer to build what he calls a "Freeway" right up through downtown Los Angeles. He has already bought out the red bus company so that it won't be in the way. This "Back-tothe-Future" variety plot-line offers a fate that will have been the case anyway - something like an Cdipus trying to outfox the oracle at Delphi. He was doomed to fail no matter how hard he may have tried, for as we know the Freeway already exists and the ride through Toontown is not unlike a ride through walls.

Nevertheless the film ends well: Roger and Jessica are saved from Judge Doom's attempts to annihilate them. The toon-melting concoction destroys only Judge Doom and his weasels, for it turns out that Judge Doom who actually looks like a human straight out of some Clint Eastwood western (read also : all those robot-monster films) is in fact a toon. He is destroyed by his own destructive chemical. Toontown is saved - though we know in our epimethean hindsight that eventually Judge Doom's plan is ultimately fulfilled.

Throughout, Roger Rabbit is kept in the frame, in the Gestell (as Heidegger would call it). Technology keeps him young, technology keeps him on the screen, technology keeps him alive. Roger Rabbit is framed. But Roger Rabbit does not stay on the set - as it is clear from the outset, the frame for cartoon is a cartoon frame. But Roger transgresses the frame. The frame does not keep cartoons in and the humans out. The genre difference between cartoons and humans breaks down. Humans and cartoons interact in the same spaces. But the humans are from another era. They do not belong to our contemporary spaces. Hence there is no problem juxtaposing the cartoon figures and the period piece personages. But when they do not stay in their proper places, in their appropriate frames, then category mistakes happen everywhere. Indeed the frame is interrupted, the limits, the barriers, and the borderlines are transgressed: toons communicate with humans, and while some cartoons look like humans, it becomes evident at the end of the film that as in the case of Judge Doom some cartoon humans are indistinguishable from humans. Differences are placed in unexpected locations. Expectations, conventions, norms, and genres keep proper places. Who Framed Roger Rabbit? interrupts those proper 
places. Where it is customary for animals in cartoons to speak, and for humans to communicate with such cartoon animals, humans do not enter into cartoon film as humans, and cartoons do not enter into period films about humans as if they were actors inter partes. Hence along with the Director Robert Zemeckis, Steven Spielberg is playing again with conventions: film quotes are perhaps even more bountiful here than in Star Wars (Lucas, 1977).

In short, Who Framed Roger Rabbit? is a postmodern film or if that is too radical a claim, it certainly operates postmodern principles. It is marked with postmodern effects. It is marked by postmodernism. But what are the marks of postmodernism? What mark does postmodernism make on modernism? How does postmodernism inscribe its marks on the artistic, literary, and philosophical practices of modernism? These are the questions posed by Roger Rabbit. Roger comes on the scene looking like Buggs Bunny, even talking something like a cross between Buggs Bunny and Donald Duck. But one wonders whether Roger is not just one new addition to the family of Walt Disney characters - as announced by Betty White on a "Walt Disney Sunday Special" devoted to a presentation of the film. Is he just part of the continuous line from Mickey and Minnie, Donald and Goofey, Huey, Dewey and Louie down to Tinkerbell, Cinderella, and Snow White? Or is there an interruption, a discontinuity, a break that accompanies the introduction of Roger Rabbit? Following Foucault, Roger Rabbit introduces a rupture épistémologique of rather significant proportions. Roger is not just another one of Disney menagerie. Roger is not just one of those cartoon heroes whom we have come to love and admire, to watch and laugh at. Roger has his problems just as Donald Duck and Goofey often do. He doesn't have the sleuthing skills of a Pink Panther, nor the perspicuity of a Dangermouse. He doesn't come from some other world like E. T. or Alf, nor does he perform great feats like He-Man or a Thundercat. He isn't some strange outerworld construction like Chewie or an Ewok. And yet Roger Rabbit in his return to the style and appearance of the original Walt Disney characters operates his place as both familiar and different. The opening cartoon - the style and age 
of the kitchen appliances - date Roger specifically as in the late 40 s. We wonder whether it is not just a rerun of one of those old cartoons. But in fact it is new. It is new and old at once. It is, as Charles Jencks calls it, "double-coded." The new is inscribed in the old and the old is constructed in the new. Roger is both old-fashionned and also very much on the vanguard. He dresses in a snappy, even outlandish fashion especially with his bright blue and white spotted polka-dotted bow tie. Roger is like the songs in Stand By Me (Reiner, 1986), Dirty Dancing (Ardolino, 1987), or Peggy Sue Got Married (Coppola, 1986), namely from another era, situated in another era - not the $50 \mathrm{~s}$ here but the 40s -, nevertheless alive, vital, and contemporary in the $80 \mathrm{~s}$ and $90 \mathrm{~s}$, Roger is a counter-anachronism, an absolete figure transformed into a postmodern hero.

How is Roger Rabbit a postmodern hero? A postmodern hero cannot be an anti-hero like all those modern heroes from Julien Sorel to Bloom to Josef K to Lucky and Pozzo. Roger offers no insights into the range and development of human consciousness. He does not shift into a realm of conciousness which is alienated, animated by a theory of association, or absurdly everyday. Roger does not exemplify a hero who is committed, faced with existential choices, or plagued with doubt and despair. Roger is at the limits of the modern and therefore reinscribed back into the modern. He looks like, acts like, and sounds like your standard, everyday modern cartoon hero. He has all the aspects of a cartoon character who gets into trouble, who has his work but just can't really cope. But which Roger Rabbit are we talking about: the one who is acting in the Baby Herman cartoon, or the one who steps off the stage, who has a drinking problem, who is stuffed into the trunk of a car and who then tries to obtain the aid and assistance of the Bob Hoskins detective? Roger has a sense of humor - he lets the detective think that he is physically bound by the handcuffs that link him to the Hoskins character. But then when a saw is brought in to remove the cuffs, Roger just slips out of the metal clamps with ease. A ruse, but a ruse with a purpose. He needed the detective to be on his side. If it were not evident that Roger can't even play his role in the cartoon correctly any more, the 
disjunction between the cartoon actor and the role played would be clean and clear cut. But it isn't. Roger had already "messed up" in the Baby Herman cartoon even though the unattentive eye might not notice. How often does one really get upset if the poor character "sees tweetie birds" instead of "stars?" The point is that a disjunction between the cartoon actor and the role acted is motivated in a rather specific way. And it is a cartoon character playing a cartoon character! Roger is already in the ironic mode. Roger is already a parody of himself. Roger is already postmodern. Roger is a parody of himself but also of all those films which themselves reflect upon filmmaking from Fellini's 8 1/2 (1963) to Truffaut's Day for Night (La Nuit américaine, 1973). The clean line between actor and acted, private life and public life, film world and non-film world breaks down. Each is pushed to its limits. And the ironic mode is particularly acute in that it is a cartoon character in relation to a cartoon. And to render it more complex, the cartoon character even walks into the human world. If Hayden White is right about the move from synechdoche to metonymy to metaphor to irony in historiography, then Roger Rabbit is already in the ironic mode. The substitution of the actor for the acted and the tension in-between breaks down in favor of a pathetic and sorry figure who is trying to keep on top of things, but having trouble doing so. He could make an excellent Willi Loman. But unlike the modern Arthur Miller figure, Roger still has some Spielraum left. He bounces back with the help of Jessica - in the classic wifely role. She loves him and sees that - with her help - they can perhaps combat the evil forces of Judge Doom. But in the end, they both cling to dear life tied to the rope/role that hangs over the solution that could mean their sure dissolution. The detective has to fight the battle to the end, the battle to the death - but like some Ninja film even when Judge Doom is flattened under a steam roller, he bounces back - since he is after all a Toon rather than a human. Only the "bad guy's" own self-manufactured solution turns out to be his end. But since he is Judge Doom, his end is his achievement. Like Heidegger's notion of end as limit, goal, and achievement, Judge Doom's hope and dream will someday come true: Los Angeles will 
indeed be traversed and scarred with Freeways, and the fantasy world of cartoons will have been radically transformed.

Roger is not a dull or uninteresting hero. As a postmodern hero, he has all the features of a modern hero: worried, battered, angry and absurd. But Roger's sense of humor makes him other. The juxtaposition of the despairing and the happy-golucky inscribes difference in the very figure itself. This inscription of difference is the operation of irony in the framing of Roger Rabbit.

And what of that framing? The frame is the encadrement, the circumscription of the character, of the tale, of the narrative. Is Who Framed Roger Rabbit? a Whodunit film? Is it one of those stories for which Hitchcock became famous? Is it a story of false accusation, search, discovery, and revelation of the true culprit? In one sense, it certainly is just that - like all those Grade B or even $C$ " modern" movies that are constructed in just that way. It could even be something like Clue or Murder She Wrote - a mystery to be solved. It could have the suspense of a Perry Mason except that there are no court scenes. But in these respects Who Framed Roger Rabbit? would be trivially banal. And to a large extent, Who Framed Roger Rabbit? is indeed trivially banal. It just looks painfully modern - except that the modern itself is put in question. The modern itself with its seriousness, its engaged search to divulge the inner self, its penetration of the phenomenological conciousness or psychoanalytic mind is ironically interrupted at every turn in Roger Rabbit. Indeed the expected moves are not what holds one's attention, but rather the interruptions. Each interruption tends to end up with another modern strategy, but it is a quotable strategy, one that can be identified, marked, and noted as of a style, of a type. In this respect, Roger Rabbit's film quotes are as plentiful as anything one might find in Star Wars, Raiders of the Lost Ark (Spielberg, 1981) or Romancing the stone (Zemeckis, 1984). And like each of the others, the film quotes are the texture of the film - the film has its identity from the disparate juxtapositions of multiple and different styles, passages and even frames that are simply borrowed from somewhere else. In this respect, Genet's Condemned Man (Un comdamné à mort) - that poem he wrote in 
prison as just one more stage in his attempt to become what others made of him by stealing, transgressing, coopting whatever he could find - including, in this case, poems from great French poets. Genet's The Condemned Man is a patchwork of lines and passages from other poems - the poem itself is pure plagiarism. And yet Genet did it, as Sartre recounts in Saint Genet, in order to establish his own identity, to become himself. Roger Rabbit is already himself. Roger Rabbit is only a fragment of juxtaposed different and contradictory styles, modes, and expressive forms. Roger Rabbit is The Condemned Man in an ironic mode.

And what of Jessica? She is not willing to let Roger be framed - especially since it also implies that she is to be framed. This is no Mickey and Minnie pair. They do not look alike they aren't even the same species. While one is a rabbit and the other is a human, they are nevertheless cartoons. So in a sense, they are the same species - both cartoons as opposed to $1940 \mathrm{~s}$ humans. And indeed, the whole question of species has been interrupted. The crucial distinction is not between an animal and a homo sapiens, it is between humans and toons. But this is the very notion of species put into an ironic mode. The classical cartoon had animals and humans but how often would there be a marriage of difference as in the case of Jessica and Roger. We are therefore not surprised to see that Jessica is much taller than Roger, that Jessica has her act together - even when she agrees to play "Paddy Cake" with the bald producer - while Roger is trying to keep out of trouble elsewhere. And what of this postmodern pair's double: the detective and his woman friend. She too is much taller than the Bob Hoskins character. One remembers that Sartre would sometime stand on a box for photos so that he would not look so short in relation to Simone de Beauvoir. And this is no Mutt and Jeff, Laurel and Hardy team this is a husband and wife. Like Jessica, Hoskins' woman friend too is the one who operates on her own, who has her own work, her own income, her own identity. They do not fulfill every feminist ideal by any means but their attitudes and activities are also not unsympathetic ones. The modern doubling (here pair matched against pair) corresponds to the modern tradition that 
carries through Dostoyevsky's Golyadkin, Proust's two sides (Swann and Guermantes) and Conrad's Secret Sharer. Yet these pairs do not constitute a Jackie Gleason-Audrey Meadows-Art Carney-Honeymooners any more than a Mickey-MinnieDonald-Daisy doubling. On the other hand, they do not also dissolve into an Bob Carol Ted and Alice combo either. The modern pair is once again framed, interrupted, and reinscribed in an ironic postmodern tone.

Robert Graham's 1984 Olympic Arch in Los Angeles made of bronze, metal and granite and set in front of the Los Angeles Memorial Stadium makes the postmodern point most succinctly. The arch has two rounded columns, a flat beam across the top of the two columns with something like a Greek frieze: front and back of a muscular nude male and a muscular nude female athlete. None of the four figures have a head - the Greek and Roman statues that lost their heads in war, ravage, or accident are now taken as a mark of the classical — as if they had been constructed that way. The same is true of the two reliefs at the pediments of the columns and in the forms of the two large statues that balance the beam outside the columns. They have the shape of a Greco-Roman Michelangelo standing on two gold conic shapes. And they have no heads. The tribute to atheletes of the world - and like the Unknown Soldier, they need not have the identity that a face and head carry with them. Like the Stanford Campus arch leading into Memorial Church or the Paris Arc de Triomphe with the Obelisk of the Place de la Concorde fitting - from a perspective — neatly under the arch, the Olympic Arch frames the Roman-Romanesque arch - the rounded form that one finds in De Chirico paintings and that also marks many postmodern buildings. The style however is more a selective quoting of the Matisse friezes that one finds, among elsewhere, in the garden of the Museum of Modern Art in New York. Matisse and Greco-Roman statues juxtaposed, quoted, and integrated offer a fabric, a text that can be read with the same kind of intensity that medievals could read Stained Glass Windows in Churches and Cathedrals. These statues and sculptures, these films and cartoons, are coded. They can be read in detail because the codes, whether classical or 
modern, are part of Western culture. The codes are not consistent in the sense of continuity. They are marked with breaks, interruptions, differences. Each individual element of the Olympic Arch is coded in a particular way: Roman, Romanesque, Renaissance, Michelangelo, Matisse, De Chirico. The pieces repeat many different texts. What they quote is incorporated - but without totality - into a texture. And the texture constitutes the sculpture, the building, or the film.

Roger Rabbit is marked with elements from the cartoon, film, and detective novel world. The marks or traces are everywhere. When the private eye steels his courage, puts cartoon bullets in his gun, and drives his car headlong into Toontown, he might as well have been C. S. Lewis' character entering the fantasyland of Narnia through the Wardrobe. And there he finds a world peopled with all the familiar cartoon characters from every imaginable cartoon show. There is no time to identify them all one notices only a few on the first viewing. It is a cornucopia of familiar figures and characters. They are our friends. And yet for the detective they are alien, threatening, dangerous. He is unsure of them - he enters their world like Luke Skywalker intruding the world of Darth Vader's Empire, or He-Man piercing the walls of the Snake Castle. He is sure that they killed his brother, and he is put off by them. It would be like Simon and Simon without the other. Bob Hoskins remembers his brother. His brother is present as absent. And the Toons are a potential threat. But the detective manages somehow — for him, all those familiar cartoon characters constitute a unit. For one more sympathetic, this is a world of joy and excitement - it is one's childhood come alive (at least one who has been watching Television since childhood). All the different tales are there marked, identified with a code, and figured with a signifier. It is a north American child's world come alive again. It is surely much as if one, who knows all the saint's lives and parables with the appropriate passages from the Bible, could sit in Church and observe their intimate detail

Whose Afraid of Virginia Woolf? (Nichols, 1966), Who is Killing the Chefs of Europe? (Kotcheff, 1978), - the genre is clear. But then who did frame Roger Rabbit? Was Roger framed 
by Mr. Maroon so that he could put the squeeze on the struggling rabbit? But when Maroon is killed, doubts arise. Then it appears that Roger killed Maroon - furthermore the Bald Producer also turns up dead. Did Roger knock him off too? By this point, it is clear to the private eye that Roger has been framed - but framed by whom? By Judge Doom - who has ulterior motives of his own? Indeed, one would have difficulty saying exactly who did frame Roger Rabbit - unless one could simply report that Roger was framed by his architects - the writers, directors, and producers who made him. To say that he was framed - as the American Constitution was framed by the Framers - identifies the respects in which Roger is designed, constituted, and rendered meaningful. Or perhaps one should say just straight out that Roger - or is it Roger, the film too is framed by Modernism itself. He would attain his status, meaning, and role by the ways in which he and the film place limits on modernism, bring modernism to its limits, show the tired worn out aspects of modernism. It can be fatiguing to try to be new all the time. And the modern has incorporated within it the expectation of the new, the excitingly adventuresome, the non-traditional. Roger is older than the new. His success does not depend upon being the "newest addition to the Disney cast of characters." In fact, Roger has elements of many of them. And yet he marks the differences among them. As Lyotard puts it, the Postmodern is already Modern. It must become postmodern in order to be modern. Roger cannot totalize anything. He can only offer fragmented pieces of different styles, characters, and fantasy elements.

Does Who Framed Roger Rabbit? " [...] put forward the unpresentable in presentation itself” (Lyotard, p. 81)? According to Lyotard, the postmodern - in the modern - accomplishes this seeming contradiction: the unpresentable in presentation itself. In an age of He-Man, Thundercats, Transformers, Alf, E. T., Smurfs, and perhaps still Alvin and the Chipmunks, Roger Rabbit is an impossible construction. Roger is an anachronism. Thoroughly "of the modern," yet without a place in the new Olympus of cartoon heroes. Roger could hardly count as a Superhero, an Extraterrestrial, an inventive sleuth. Roger is 
too ordinary a cartoon figure. He is not really even funny. $\mathrm{He}$ is more pathetic than anything else - not to be admired, not to be extolled, not even to be pitied. Roger is an unmistakably ordinary cartoon character. If not careful, he could be mistaken for the Easter Bunny. And in the light of his drinking problem, if he is not careful, he might not make it out of Mr. MacGreggor's garden. In a way, Roger belongs more in a Tennessee Williams, Eugene O'Neill, or Arthur Miller play than in some high-powered Whodunit. And yet Roger is not out of place in the film. $\mathrm{He}$ is "unpresentable in the presentation" because he operates difference within the all-too-familiar at every stage of the film. There is nothing classically sublime about Roger Rabbit, and yet difference in the ordinary abounds. But it is not because Roger is ordinary that the film is modern. It would have been ordinary in 1947 perhaps - but the anachronistic elements comprise the present of the film. And Roger traces out the modern - puts it in quotes - and thereby articulates - or better: marks - the postmodern in the modern.

State University of New York at Stony Brook

WORK CITED

Lyotard, Jean-François. The Postmodern Condition. Minneapolis: University of Minnesota Press, 1984. 